\title{
The Contents and Structure of Innovative Activity in the Russian Economy
}

\author{
Elena Sibirskaya ${ }^{1}$, Olesya Stroeva ${ }^{2}$, Nadezhda Serebryakova $^{3} \&$ Innara Lyapina $^{4}$ \\ ${ }^{1}$ Plekhanov Russian University of Economics, Moscow, Russia \\ ${ }^{2}$ Russian Presidential Academy of National Economy and Public Administration, Moscow, Russia \\ ${ }^{3}$ Voronezh State University of Engineering Technologies, Voronezh, Russia \\ ${ }^{4}$ State University - Education-Science-Production Complex, Orel, Russia \\ Correspondence: Elena Sibirskaya, Plekhanov Russian University of Economics, 36, Stremyanny per., 117997, \\ Moscow, Russia. Tel: 7-910-269-0035. E-mail: e-sibirskaya@rambler.ru
}

\author{
Received: August 20, 2014 Accepted: September 12, 2014 Online Published: November 14, 2014 \\ doi:10.5539/ass.v10n23p51 URL: http://dx.doi.org/10.5539/ass.v10n23p51
}

\begin{abstract}
This article is based on the scientific literature about Russian innovative economy. It has the new conceptual content of innovative activity. The works of the native and foreign scientists are investigated and analysed in it and six main schools of sciences are presented there. The concepts of "innovations", "the innovative environment", "the innovative process", "the innovative activity" and their impact on the national innovative system are articulated there. In its turn this system has to create legislative and normative bases which interact with the system of the generation, the distribution, the introduction and the knowledge and results use and also with the innovative activity infrastructure, with the education, production and market spheres. Thus we confirm that the national innovative system has to lead the country to an innovative way as by dint of the national innovative system institutes the innovations have to be concentrated and directed where they are necessary. Also, the questions under consideration of these articles emphasize that the innovations are the main condition of the national economy economic growth of Russia. The question is carrying-out of priority innovative programs and projects, an increase of the scientific development use, manufacturing application of fundamental and applied researches results. It is important because of the innovative activity in Russia has increased under the influence of a great demand of scientific and technical products from the state and non-state sector of economy. Also it is important to accent that the innovative activity is of territorial natural though the regional innovative processes are inseparably linked with the solution of the national scientific and technological problems.
\end{abstract}

Keywords: innovations, innovative environment, innovative process, innovative activity, national economy

\section{Introduction}

The Russian economy is a difficult economic, social, organizational, scientific and technological system. It has the collective economic benefits which consist of its separate opportunities which were accumulated in the process of functioning. Among them we can separate the natively - resource, production, labor, scientific and technical, etc. (The National Economy, 2012).

The conception of the innovative processes increasing importance in the world refers to the main directions quantity of modern scientific thought. The emerging of the new direction of the researches which are necessary for more effective solution of an intensification and acceleration problems or "the innovation science" is explained by it. The innovative way of the developments represents the operated development of human activities different spheres aimed at an optimization, an improvement, "response delay" and conservatism negotiation.

For the Russian Federation the first decade of the twenty first century became the economic growth stage. The basis of this phenomenon became a sale of natural resources which the country has. The very large profitability of the resource-based economy did economically ineffective an investment into innovations for business and the state. In the last decade for the country there were three unique factors which have defined a sustainable development of economy: the petroleum price has constantly growing for 8 years; the petroleum price has grown to very high level which did never repeat in the history - 95 dollars in the realized price in comparison to all 
previous periods of supervision; after big falling of oil extraction in the 90th years the Russian Federation increased from 2000 till 2004 to $10 \%$ of incremental oil production (Chubais, 2010).

"It was the unique period. The special progress of the Russian Federation is explained by these factors. The aforecited three factors won't develop together, maybe, the next 10 years and in 20 or in 50 years. According to analysts, such successful combination of circumstances shouldn't be expected", - Anatoly Chubais commented on this fact. The specified circumstance does necessary the revision of a state policy for the purpose of its system orientation to the country development of the innovative activity. For the reaching stability and the economy sustainable development it is necessary to put measures into effect for its modernization and to make leaving from resource dependence. The base of modernization process is use of modern technologies, research-and-development activities, i.e. innovations.

According to the opinions of the experts, such as A. L. Kudrin (2010), E. S. Nabiullina (2014), I. I. Shuvalov (2013), E. V. Popova (2012), at the present time the innovative activity faces some problems: the outdated tax legislation which is inappropriate to requirements of innovative economy and needing revision; the imperfection of the legal and regulatory framework regulating the innovative activity and questions of the intellectual property; the problem of administrative barriers and corruption; the underdeveloped innovative infrastructure of the enterprises; the insufficient level of the state support in the sphere of regulation and financing of economic systems innovative development; the deficiency of the enterprises modern base for development introduction because of the necessary equipment depreciation or the their lack. Many industrial enterprises are characterized by high resource-intensiveness and power intensity of production that is supported with high level of the productive facilities depreciation. Because of the enterprises fixed capital backwardness the economy becomes unreceptive to investments into researches and development; the disinterest of the credit organizations in risk innovative business financing; the lack of the skilled labour which can be capable to manage the innovative process effectively, and this problem is felt at all levels of management, both the country and the separate enterprises.

An existence of the opposition to innovations phenomenon happens for the next reason: the fear before all new things. Most of all it is expressed at the transitional moments, particularly at crisis moments when the social psychological uncertainty and the introduction of the new things is considered as a threat. From the point of the investor view the emergence new technology which is more effective than investor's and is constructed on the new principles creates the threat to the existing innovation. Therefore investors try to impede it for a time, at least for so long as previous investments won't pay off (Saifullina, 2010).

The most part of the economic systems innovative development problems of all levels has the overall character and can be decided at the federal level. The tax problems, the legislative guarantees of investments, the questions connected with the rights for the intellectual property and also the state infrastructure support which create the significant opportunity for their development appertain them. Other part of these problems can be solved by dint of the increase of economically active population in the innovative sphere. The complex of the economic systems innovative development problems makes a problem scope of the innovative activity which is reflective of the true situation in the sphere of the innovative activity and can promote the development of further actions for their solution.

Thus according to the our opinion the problem scope of innovative activity is the complex of the economic systems innovative development hindrances which stops the effective advance of innovative activity and impedes the economy competitiveness increase and the processes of its transformation into the innovative. In this regard we confirm the need of the innovative type of the development formation for Russia and for its regions. Therefore we believe that learning of the developed opinions in the scientific sphere about the concepts of "innovation", "innovative activity", "innovative development" and articulating their contents are very important.

\section{Methods and Materials}

The fundamental and monographic works which devoted to the theoretical and practical questions of the innovative processes management in the modern economy and works of native and foreign authors, the theoretical and applied development of native and foreign scientists in the sphere of ensuring innovative development, the works which devoted to the questions of stimulation and activization of economic operators innovative activity are formed the theoretical basis of the research (Freeman, 1987; Harrod, 1933; Boudeville, 1966; Kaniran, 2005; Stoneman, 1995; Lundvall, 1992).

The empirical base of the research and the source of ensuring the conclusiveness of issues and conclusions presented in the work were the official data of Federal State Statistics Service, the native and foreign periodical 
press; the results of researches of scientific centers editions including Institute for the economy of the Russian Academy of Sciences, the materials of statistical surveys including the results of experts' reports and opinions, the data of reports about the innovative, financial and economic activity of enterprise structures, the materials of the Russian and international scientific and research-to-practice conferences, seminars, "roundtables", the information sources and the Internet.

The regulatory basis of the research is Constitution of the Russian Federation, legislative and regulations of the Russian Federation including The concept of long-term socioeconomic development of the Russian Federation for the period till 2020; the Strategy of innovative development of the Russian Federation for the period till 2030; the Strategy of the science and innovations development in the Russian Federation for the period till 2015; the legislative instruments of subjects of the Russian Federation.

The methodological basis of the research is:

- the system approach to the innovative processes research in national economy and multilevel approach to control system improvement at micro- and mesolevel;

- the complex of theoretical and methodological issues and the concepts which is the basis of the problem solution of the productivity increase of the innovative processes management including the theories and concepts of productivity increase of economic systems management, the estimation procedures of the innovative activity efficiency; the concepts of the differentiated approach realization to the economic systems management.

For the solution of performance targets the authors used the following methods of research:

- the theoretical such as the analysis and systematization of monographic and periodic literature about the research problem; specification and generalization; the analysis of the program and normative documents which provide the territories innovative development, etc.;

- the empiric such as learning of innovative activity experience of the enterprises and organizations, data collection procedures (the method of observation, Delphi approach, polling);

- the statistical such as the statistical analysis and substantial interpretation of the research results; the factorial analysis and correlation and regression analysis, their mathematic treatment, grouping, etc.

\section{Describing the Domain}

The debating points about the innovations role and importance show the difficult complex of interests in recent years. At the present time the innovative policy formation is the most important condition of basics developing of a sustainable growth at the level of the enterprises and the organizations, regions and the state. The innovations are the main transformation components of any economic system. The realization of equation planning allows the organization of the development programs of investment and innovative processes, and also the most exact assessment of their realization efficiency. The Russian Federation innovative development has to be balanced with the investment processes. It will allow combining forces and resources of the state and the business sector for their development. In our opinion the activity which directs on the innovative projects delivery, the innovation process are explored by academic community and connected with the different rendering of the term "innovation".

At the moment the large volume of academic papers concerning innovations and innovative activity is collected, the quantity of literature on this subject constantly increases. But while there isn't clear understanding of this phenomenon. The word for word translation of the English word "innovation" into Russian means "introduction of the new technologies, products and services". The innovations are interpreted in several aspects: 1) as any improvement and it refers to the social sphere, science, production; 2) as a process or a result (a product). The wide range of the phenomena which is back of this word explains the reason of disagreements concerning the concepts "innovation" and "innovative activity", but doesn't solve them. The different authors connect the term "innovation" as "any improvement" genesis with the different population activities and date it differently.

Thus, the analysis of economic literature showed us that scientists consider the category of "innovation" unequally depending on the purpose of the research. Authors investigated and analysed the materials of native and foreign scientists. Therefore six main schools of sciences are created:

- the school of science «Innovation is developments» (Voldachek L., Gamidov G., Goldstein G., Schumpeter Y., Yakovets Yu. etc.);

- the school of science «Innovation is a result of scientific work» (Balabanov I., Glazyev S., Gokhberg L., Kokurin D., Pilipchuch V., etc.); 
- the school of science «Innovation is the process of generation, introduction, use of ideas and results» (Valdaytsev S., Zavlina S., Polushkina And. Prigozhin A., etc.);

- the school of science «Innovation is continuous activity which include the interrelation of stages of creation, distribution and practical use of an innovation» (Gvishiani D., Kabakov V., Lapin V., Medynsky V., B.'s Santo, Tviss B., etc.);

- the school of science «Innovation is the movement from the lowest to the highest or a progress» (Aganbegyan A., Blyakhman, L. Valdaytsev S., Kruglikov A., Roberts M., etc.).

- the school of science «Innovation is the change, result, process, activity, progress» (Azgoldov G., Kostin A., Sovetova O. S., Fatkhutdinov R., Jansen F., etc.).

\section{Results}

According to the president of the Union of the innovative enterprises employees of the Russian Federation Yury Pimoshenko the most effective systems of innovative activity development in the world are the systems of the USA and Japan. The USA system is based on hard legal restrictions, Japanese system is based on the nation mentality therefore the slogan of "the nation of innovative property" was proclaimed in the country. "Without the complex approach to the innovative development in the Russian Federation nothing will work out well", Pimoshenko (2012) considers.

The existing tools and means such as the Consolidated Register of the state and municipal services, the departmental analytical and information systems don't create a full-fledged basis for administrative decision making for innovative functions and services, the optimization of financial, personnel, information support of the state functions and services acting. In modern Russian conditions the system forming of the state organizations which is capable to provide "through" support of the small knowledge-intensive enterprises seems necessary. Thus obviously it is necessary to concentrate the attention on coordination of activity of already existing organizations rendering assistance to development of innovative activity (Martov, 2013).

The main tasks facing the structure of innovative activity according to the main problems of economic activity sphere are: the expansion of demand for hi-tech production, the potential investors expansion thanks to the representatives of the venture investment market and also due to medium and large business, lending financial aid at the earliest stages of the innovative projects formation, help in search of partners and different rendering services in "maintenance" of implementation of innovative projects, the assistance in gaining access to the most available office and industrial spaces, the information support.

Thus the innovative activity structure of Russia can be presented schematically (Figure 1). In our opinions the institutes of the Russian innovative activity structure can be divided on traditional and modern in classification.

The appropriateness of such division can be proved from the institutional theory positions. This role defines the efficiency of institutes of innovative activity structure. Therefore such institutes formation happens to the purpose of decrease of transactional cost saving. The structure which exists in Russia till 1990th (conditionally called "traditional") didn't aim at transactional cost saving because of the conditions of a planned economy. The followed market reforms caused the structural changes in economy and the transformations at existing innovative infrastructure institutes. However, it is extremely difficult to transform the institutes in short terms therefore in market conditions the planned economy elements were incapable to reduce the transactional expenses effectively and therefore they became noncompetitive.

It is also possible to say that the readiness phases for innovative development are created in Russia. The first phase is the "organizational and administrative innovations" and it includes the business restructuring, the introduction "forgotten" planning and budgeting, updating and the personnel training in the innovative sphere, the computerization of administrative information processing, the foresight forecasting, etc. The second phase is "market innovations". It is based on the formation of marketing and distributive networks and also logistic chains.

The third (modernization) phase is "technological innovations". It specifies that there is an active the equipment updating, a purchase of technologies and ready technological lines in Russia. Also the new innovative structures are created. The fourth phase ("the transit to innovative technologically development") shows that the search $R \& D$ are done, the corporate scientific research institutes and venture funds are created, the profile research teams is attracted, the active patent and license policy is conducted. 


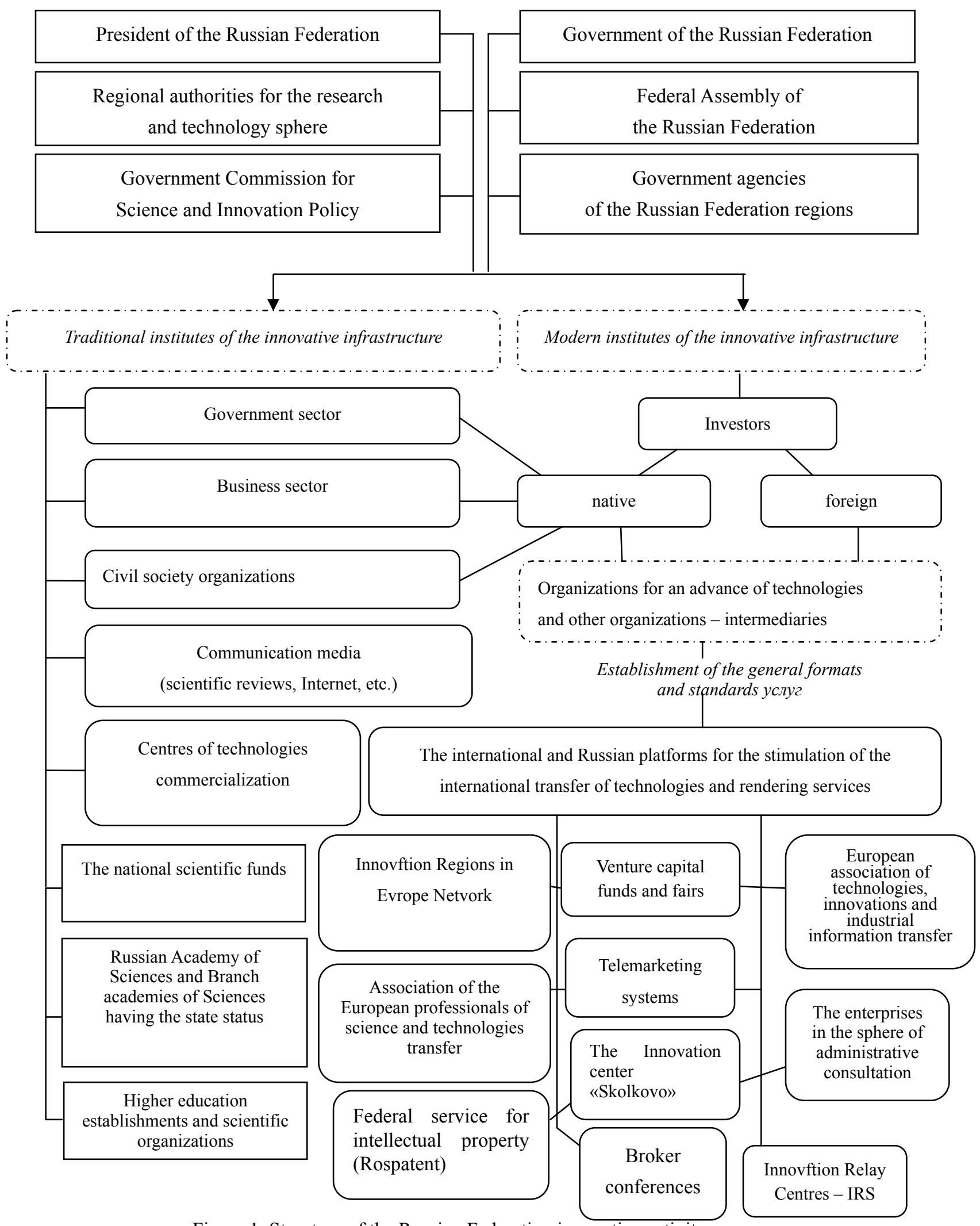

Figure 1. Structure of the Russian Federation innovative activity

\section{Discussion}

It should be noted that, it is impossible to allocate for the top or last place any of these schools as scientists discussions are held constantly and each school of sciences has to be. Authors consider that there is a need to 
regard the concepts and features which are connected with the innovative activity or intersected with it. Both the scientists, and the managers consider the relation between innovative and research work is indisputable. But it is necessary to find out the differences between these features, otherlike it will be impossible to share scientific and innovative results of higher education institutions activity.

In our opinion, innovations are a form of interaction of scientific institutions with scientific production con-sumers. The representatives of all kinds of practice are the scientific production consumers, and all types of knowledge can be presented as a product of scientific activity. And if to consider a full range of innovations, it is clear that fundamental knowledge is consumed by representatives of applied science, and they carry out their processing in applied aspect. Ultimately the fundamental knowledge in recycled (technological) aspect also becomes needed. But such long process seldom causes interest of practicians, more often than not they will use the results of applied researches therefore production of applied knowledge, from the point of view of receiving profit, is more remunerable.

For clearer understanding of the innovation phenomenon from positions of economy and marketing strategy it is important to pay attention to next aspect. The experience shows that first of all the most successful innovations are new marketing concepts, and there is a concept of benefit in the forefront. Very often the consumers need not a new product which can be considered as the invention, but the receipt of profit from already available product (Novikov, 2006).

One more circumstance makes impact on understanding of a basis of innovations. Now practical activities are characterized by constant variability, reform, i.e. innovativeness. Innovations are more often than not realized in terms of projects, and their creation and the realization can't be enabled without the developed scientific thinking. The process of rapprochement between science and practice has to become one of differential characteristic of our time, and it is carried out through innovations which are necessary to resolve the collected problems or at least to offer the ways of problem solution.

Thus, the innovations are one of instruments of resolving the problem of estrangement between scientists and practicians. Apparently, it is necessary to say about a certain objective dialectic contradiction between the scientific and innovative phenomena. The scientific activity is the research of an existing phenomenon, a verification, production of new theoretical or applied knowledge, and innovative activity is a method, the designing something. The point to be emphasized is that: the innovative activity begins with having the idea in consciousness of innovation subjects (scientists and practicians), i.e. with scientific activity. However the full innovative process represents a complex of procedures and means thanks to which the discovery or idea passes into an innovation, and it occurs not only in the sphere of material production and the corresponding sciences, but also in social practice and in social sciences. However an innovation is represented in the documented form of development in social sciences more rarely than in technical sciences.

After such procedures the improvement can pass into an innovation. The sense of the word "introduction" assumes the inclusion, the implementation something to somewhere, i.e. as this concept the pedigree makes us to understand not the phenomenon of stating informative (scientific) order, but the phenomenon active, processed or technological character. From the general scientific concept of the main structural levels realized in procedures of system approach, it is known that initial, original state is the phenomenon essence, and these essence remains in all subsequent evolutionary forms. Other methodological postulate is known: more private phenomenon can't contradict more general phenomenon, i.e. the phenomenon of higher order. Thus, on the one hand, it is impossible to create an innovation, passing technological study of idea, and on the other hand it is difficult to create essentially new technology without relying on scientific idea. It is an organic communication between innovative and research activity.

The consideration of innovations from technological and economic positions well works in the material sphere. However the application of concepts and terms which are generated in the economic environment, to the spiritual sphere is the thankless job, because it contradicts the nature of scientific and art work. All scientific researches are directed on receiving new results, and one of the criteria of art work is a novelty of idea or the ways and means of a brainchild. Therefore the science and art are classified as productive kinds of activity. But the social sphere isn't settled by science and art; it is directed on the protection of the person, on the creation of conditions for preservation of its health, for its socialization and development, for protection of its rights and property. There are many types and reproductive (not creative) activities in the social sphere, and they can't function without powerful economic component. In any practical activities the economic indicators successfully work as universal measuring instruments of efficiency. Unfortunately, the humanists hardly investigate economic problems and therefore it is especially difficult in the social sphere to be engaged in reforms and the innovations 
which efficiency is measured by indicators of expenses and profits. But social innovative projects look very inconclusive without these indicators (Sibirskaya, Stroeva, Gubareva, \& Mikheykina, 2014).

Thus, the commercialization of the results is designated as one of identifiers for innovative activity. But further innovations life cycle turns it into the phenomenon of ordinary life which is deprived of novelty. Therefore it loses the right to be called an innovation. The innovation introduction into the production and the providing its results on the market, and further long usage of an innovation, its transformation into the element of daily practice which is bringing in the income, finish the innovative activity; transfer it to the category of reproductive usual production and commercial activity.

The innovative activity is the activity which include all above-named production cycle, and also activities on conditions creation for innovations, on management of processes of innovations creation, and on creation of its organizational and material infrastructure (Sibirskaya, Stroeva, Khokhlova, \& Oveshnikova, 2014).

From the point of engineers view the innovative activity is a production and introduction of intellectual property. Thus we bring to notice that such definition isn't sufficient as it is not completely covers the economic and property bases of activity as it is accepted among businessmen.

From the point of business view the innovative activity is the stages of realization of the innovation projects which are a kind of capital investment projects. And it is known that innovation projects look for investors for the organization or acquisition of real tangible and fictitious assets while capital investment projects vary the capital investments in financial assets and they are not the innovative projects (Sibirskaya \& Stroeva, 2011).

As regards the innovative development, it is characterized by an increase of innovative capacity (human potential, the science and innovation expenses); the increase of innovative infrastructure and investment climate indicators (the indicators which characterize the organizational capability, the existence of prospective investors); the innovative activity performance (the innovative activity cost-effectiveness). Thus, the innovative development is the positive dynamics of indicators which characterize innovative activity (Stroeva, Sibirskaya, Khokhlova, \& Oveshnikova, 2014)).

\section{Conclusion}

According to the draft of the Federal law "About innovative activity and the state innovative policy" "the innovative activity infrastructure" is the organizations which provide the services are necessary for the pursuit of innovative activity to innovative activity subjects (the Federal Law "About Innovative Activity and the State Innovative Policy", 2011). Also in the draft of this law it is specified what specifically types of service the organizations can render for the pursuit of innovative activity (Figure 2).For our opinion the special conditions are necessary for effective innovative development that is the created conditions by the innovative environment. The innovative environment is an integral part of effective innovative system formation. The concept of "the innovative environment" is the current certain social and economic, organizational and legal and political environment which provides or slows down the innovative activity development (The innovative environment (external and internal factors), 2014). Authors consider that the innovative activity development is possible under systematic motion of managerial decisions which circulate in the conditions of innovative activity and are accepted in the innovative environment.

By reference of the standard definition of "innovative process", it is possible to say that the innovative process is a process of the creation, distribution and innovation use, that is a complex of new ideas and offers which can be potentially carried in execution and can become a basis of any innovation upon condition of their use immensity and efficiency of the results (The innovative process, 2014).

In the article "National Innovative System of Russia" the scientist Chebotaryov N. F. considers that the national innovative system is the complex of the connected components which take part in the creation, commercialization and consumption of new knowledge and the technologies providing a sustainable development of the national economy (Chebotaryov, 2007).

Authors consider that exactly the national innovative system has to form the regulatory environment by dint of the system of generation, distribution, introduction and use of knowledge and results, also by dint of innovative activity infrastructure, education, production and the market.

In the current context it is supposed to construct the whole system which will provide the economy with new technologies and products nationally. We suggest that the national innovative system has to lead the country to an innovative way as the innovations are concentrated and directed by means of national innovative system institutes exactly there where they are necessary. 


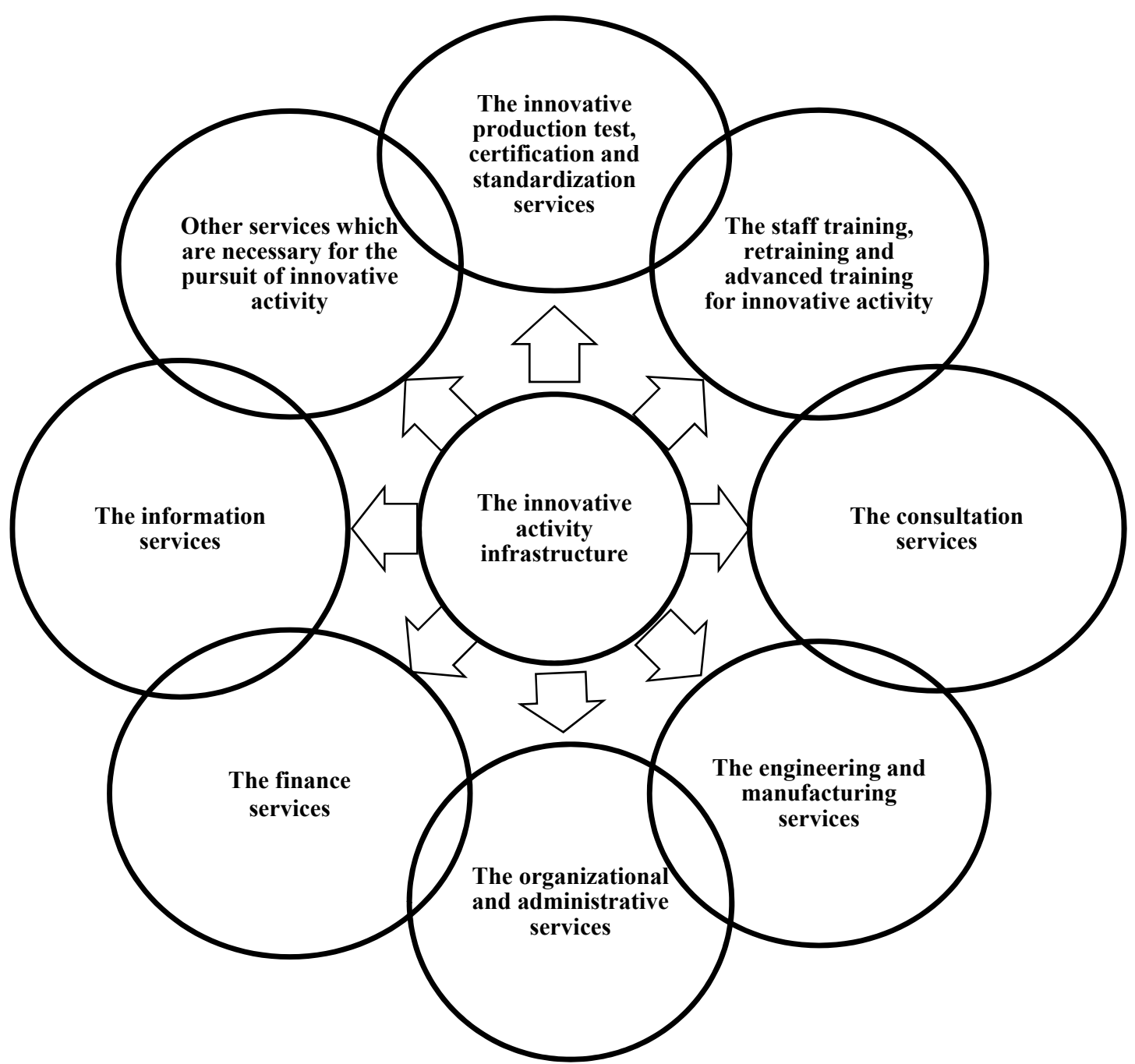

Figure 2. The innovative activity infrastructure

Thus, under the conditions of globalization, an important factor of stability and economic independence is the ability of certain regions and the country to react to changes internal and outside environment quickly, to realize the fast adaptation by means of huge instruments of innovative policy. Therefore, the relations between global and local parts of the national policy are multiplied by the requirement of the good organization. It is connected with that the regional environment defines competitiveness of native business in many respects.

\section{References}

Boudeville, J. R. (1966). Problems of Regional Economic Planning (p. 11). Edinburgh.

Chebotaryov, N. F. (2007). The national innovative system of Russia. Audit and financial analysis, 3, 1-9

Chubais, A. B. (2010, January 21). Theses of the International conference "Russia and world: invitations of new decade". Moscow. Retrieved April 14, 2014, from http://www.rusnano.com/Post.aspx/Show/24766.

Freeman, C. (1987). Technology Policy and Economic Performance (pp. 1-5). London: Pinter Publishers.

Harrod, R. (1933). International Economics (pp. 566-576). L.: N.Y.

Innovative environment (external and internal factors). (2014). Retrieved May 25, 2014, from http://managment-study.ru/innovacionnaya-sreda-vneshnie-i-vnutrennie-faktory.html (Accessed on)

Kaniran, H. M. (2005). Best practicesin ERP software applications (p. 15). Lincoln.

Kudrin, A. L. (2010, January 21). Theses of the International conference "Russia and world: Invitations of new decade". Moscow. Retrieved March 8, 2014, from http://government.ru. 
Lundvall, B. A. (1992). National Systems of Innovation. Towards a Theory of Innovation and Interactive Learning (pp. 23-44). London: Pinter Publishers.

Martov, S. N. (2013). Information infrastructure of the small innovative enterprises: A monograph (p. 184). Oryol: JSC Nauchnoye obozreniye.

Nabiulina, A. S. (2010, January 21). Theses of the International conference "Russia and world: Invitations of new decade". Moscow. Retrieved January 3, 2014, from http://www.economy.gov.ru

Novikov, A. (2006). The science and the practice today. The higher education, 6, 16-22

Pimoshenko, Y. (2011). The next round of official consultations in the "5+2" format began today in Vienna. Retrieved March 23, 2014, from http://mkspmr.idknet.com/content/view/7954

Popova, E. V. (2010). About the concepts of the Federal law "About the state support of innovative activity in the Russian Federation". Innovations, 2(136), 3-9

Saifullina, S. F. (2010). The problems of the Russian enterprises innovative development. Achievements of modern natural sciences, 3, 171-173. Retrieved January 30, 2014, from http://www.rae.ru/use/?section= content\&op=show_article\&article_id=7784511

Shuvalov, I. I. (2010). Theses of the International conference "Russia and world: invitations of new decade". Moscow, the 21 of January, 2010. Retrieved May 19, 2014, from http://government.ru

Sibirskaya, E. V., \& Stroeva, O. A. (2011). The basic provisions, determinants and conditions of the innovative development management. The Herald of the Oryol State Institute of Economics and Commerce, 1, 5-10

Sibirskaya, E. V., Stroeva, O. A., Gubareva, L. I., \& Mikheykina, L. A. (2014). The monitoring of the subject and object of the economic activity population in the innovative sector. Life Sci J., 11(8s), 292-296.

Sibirskaya, E. V., Stroeva, O. A., Khokhlova, O. A., \& Oveshnikova, L. V. (2014). An analysis of investment-innovation activity in Russia. Life Sci J., 11(7s), 155-158

Stoneman, P. (1995). Handbookof the Economics of Innovation and Technical Change (p. 25). London: Blackwell.

Stroeva, O. A., Sibirskaya, E. V., Khokhlova, O. A., \& Oveshnikova, L. V. (2014). Regionalization of the innovation management process. Life Sci J., 11(8s), 297-301

The draft of the Federal law "About innovative activity and the state innovative policy". (2011). Retrieved April 12, 2014, from http://www.bestpravo.ru/rossijskoje/di-gosudarstvo/q7g.htm

The innovative process. (2013). Retrieved January 18, 2014, from http://www.bestpravo.ru/rossijskoje/digosudarstvo/q7g.htm http://dic.academic.ru

The national economy. (2013). Retrieved April 4, 2014, from http://www.grandars.ru/student/nacekonomika/nacionalnaya-ekonomika.html

\section{Copyrights}

Copyright for this article is retained by the author(s), with first publication rights granted to the journal.

This is an open-access article distributed under the terms and conditions of the Creative Commons Attribution license (http://creativecommons.org/licenses/by/3.0/). 